\title{
Quality of Romantic Attachment, Forgiveness, and Altruism in Parents of Children with Special Needs and Parents of Regular School Children
}

\author{
Bagher Ghobari Bonab, \\ Faculty of Psychology, University of Tehran, \\ Farzaneh Motamedi, \\ PhD Psychology, \\ Corresponding author: Email: f.motamedi@gmail.com, \\ Fatemeh Shabizade \\ Faculty of Psychology, University of Azad Birjand \\ Shohreh Sadeghi \\ MA, University of Azad Birjand
}

\begin{abstract}
The aim of the current study was to investigate the relationship between forgiveness, quality of romantic attachment with altruism in parents of children with special needs and regular school children. In this study, 275 individuals (144 parents of regular school children using cluster sampling and 131 parents of children with special needs using available sampling procedure) were selected. In this study Enright forgiveness inventory (Enright, 1977), Adult Attachment Inventory (Hazen\& Shaver, 1987), and altruism (Ashton \& et al., 1998); were used. Analysis of data was performed by using multiple regression analysis. Results of the analysis revealed that in parents of regular school children there was a significant negative correlation between insecure attachment to spouse and cognitive, emotional and behavioral domain of forgiveness. Whereas in parents of exceptional children there was a significant negative correlation between insecure attachment to spouse and cognitive and behavioral dimensions of forgiveness. Multiple regression analysis revealed that in mothers of children with special needs and regular school children quality of attachment to the spouse was a significant variable in determining the forgiveness (cognitive, behavioral and emotional dimension of forgiveness). The quality of attachment is a significant variable in determining the magnitude of forgiveness.
\end{abstract}

Keyword: forgiveness, quality of attachment to spouse, altruism, exceptional parents, regular school children's mother. 


\section{INTRODUCTION}

Attachment is a deep emotional bond between special individuals in during the life span, in a way that having interaction and relationship with them result in feelings of jubilance and joy in the person and that when the person is stressful, those people make him/her feel calm. In fact, the attachment is a special emotional relationship in which joy, care, and serenity are exchanged (Chun Thai, 2012). Bowlby (1980) believed that infants elicit their experiences with their caregivers, so as to produce the internal attachment aspects or internal activation patterns about themselves or others and these attachment aspects shape the expectations related to relationships and future; and on the other hand, the schema include assessment-oriented beliefs about one's self and others. Attachment representations can be conceptualized as cognitive schemas for relationships, which have been shaped through a response to the childhood experiences with the caregivers (Wiederman \& Allgeier, 1996). There are three main styles of attachment: secure attachment, insecure-avoidance attachment, and insecure-anxious attachment. A child who has the first style i.e. secure attachment tends to consider others as reliable and himself as a person worthy of being cared and loved (Kardatzke, 2009). The adults who have secure attachment style tend to describe their romantic relationships as happy and reliable. They can easily approach the others and tend to support their life partner. In their study, Hazen and Shaver (1987) showed that about 56 percent of adults had a secure attachment style. The individuals who had this style showed a tendency toward describing their relationships experiences in a more positive way and tend to continue their relationships more than that of insecure-anxious participants (Kardatzke, 2009).

Avoidance attachment is related to the activation patterns of others in the relationships. The individuals who have this style deny vulnerability and tend to get scared of intimacy and claim that they need no close relationships (Wiederman \& Allgeier, 1996). The adults who have avoidance attachment style are scared of intimacy and emotional ups and downs, have a problem in trusting the others and are worried about getting too close to others. They do not believe that romantic love is going to last (Hazen \& Shaver, 1987). 
Anxious attachment is related to the activation patterns of oneself in the relationships. It means that these individuals tend to have a weak pattern of themselves in the relationships and are worried about being left or disliked and seek for reassurance and negative emotional experience. Wiederman (1996) stated that the adults with insecure-anxious attachment style describe love as a kind of obsession and tend to experience the kind of romantic relationship which is determined through emotional ups and downs, excessive envy, and strong wish for an emotional bond (Hazen \& Shaver, 1987). They seek for intimacy and, more than anything else, are afraid of rejection (Pietromonaco \& Barrett, 2000).

According to attachment theory, the individuals who have insecure-avoidance style and also the individuals who have insecure-anxious attachment style are both categorized as insecure people category and the difference between them and the individuals who have secure attachment style was evident, especially, at the time of threatening situations because the people who have insecure attachment style show a deterrent behavior in these situations but the feeling of the people who have secure attachment style reduces their need to watch over themselves and lets them move the mental resources including the act of considering other people's perspective and adjusting the anger which is a key mechanism for irritation (Brunette, Taylor, Worthington \& Forsyth, 2007). Therefore, the people who have secure attachment can understand and respond to others easier than the people who have insecure attachment because the reactions like compassion and empathy are the products of caretaking behavioral system (Mikulincer \& Shaver, 2001; Mikulincer \& Shaver, 2003). Researchers believe that whenever the individuals feel more secure and are less threatened, they would have more psychological resources to donate to others. According to attachment theory, the effectiveness of increasing the secure attachment is depicted as a method for growing empathy and altruism (Mikulincer \& Shaver, 2005). Less frequent altruistic and helping behavior in a person might be related to low levels of empathy and prosocial orientation toward other people, which is called personal distress (Batson, 1991). Based on this theory and some studies (Gillath, Shaver \& Mikulincer, 2005), the individuals who gain a high score in avoidance attachment dimension and, in fact, their behavior is shaped by attachment deactivation strategy distance themselves from other people's sufferings and problems which leads to excessive reduction in theirs feeling of altruism. On the other hand, 
the individuals who gain a high score in attachment fondness and easily, because of some internal reasons, become anxious respond to other people's suffering through personal anxiety (Mikulincer \& Shaver, 2005).

Although the attachment style of the individual is shaped during initial years of life, it continues during all life and affects different dimensions of the individual's life such as intimate relationships, love, marriage, and even his/her marital adjustment.Some evidence show that secure attachment is accompanied by sensitive and responsive care for others. For instance, the mothers who have secure attachment style show more supporting and care fondness for their children than that of the mothers who have insecure attachment style (Crowell \& Feldman, 1991). The individuals who have secure attachment style are more sensitive to their spouse's emotional needs and claim that they support their partner more than others (Feeney, 1996; Feeney \& Hohaus, 2001; Kunce \& Shaver, 1994). Studies show that the individuals who have secure attachment style are more willing to take care of their older relatives and take pity and respond to the needs of strangers (Soerensen, Webster \& Roggman, 2002), empathic response to the agonies of other people's children (Kestenbaum, Farber \& Sroufe, 1989). In their study in 2001, Westmaas and Silver showed that the individuals who gained higher score in avoidance attachment dimension had less supportive behavior toward cancer patients than the individuals who gained lower score in that dimension; and the individuals who gained higher score in insecure-anxious dimension reported more irritation at the time of having relationship with cancer patients.

Relations between attachment theory and forgiveness has been advocated. Both of them include some constructs such as trust, relationship, empathy, and emotional adjustment. For instance, a person who wants to forgive often needs to respond with empathy and cope with the feelings of doubt, guilt, and anger. Therefore, "forgiveness means ignoring the wrongdoing and removing its side effects and is performed by the person to calm down himself, ameliorate his relationship with the wrongdoer, or do a valued behavior. It makes the individual be released from negative feelings against the wrongdoer, cope with the agonies resulted by bad behavior, and prevent any anger, distance, separation, or revenge on the wrongdoer. One can say that forgiveness and 
attachment act in a parallel manner (Toussaint \& Webb, 2005). Enright and et al. (1991) believed that forgiveness is the voluntary liberation of the agonies which are resulted by the wrongdoer's considerable injustice and is a kind of benevolent response to a wrongdoer, even though he/she doesn't deserve to be forgiven. According to this view, forgiveness is sufferer's volitional action and choice. In other words, forgiveness is an intentional and voluntary process which happens after the optional decision for overlooking (Enright, Santos \& Al-Mabuk, 1989; Fincham, 2000; Worthington \& Scherer, 2004).

Individuals' tendency toward forgiveness affects their friendly relationships, and their stress reduces as a result of the decrease in cortisol (Berry \& Worthington, 2001). The individuals who have a high level of forgiveness report more positive motivation and are more satisfaction with their life (Bono, McCullough \& Root, 2008). Studies show that forgiveness is positively related to physical health (McCullough, Witvliet, 2002; Lawler-Row, Karremans, Scott, EdlisMatityahou \& Edwards, 2008, Webb, 2003), psychological well-being (Bono, McCullough \& Root, 2008; Worthington \& Scherer, 2004) and reduction of anger (Huang \& Enright, 2000) and increase of harmony, trust, and peace (Burnette, Davis, Green, Worthington, Bradfield, 2009) it is negatively related to physical illnesses and the psychological structures which are connected to low levels of mental and physical health (Lawler-Row, Piferi, 2006; Miller, Smith, Turner, Guijarro, Hallet, 1996; Vandervort, 2006). The individuals who show high levels of forgiveness have less depression, anxiety, and problems in interpersonal relationships (Ghobari Bonab, Kivanzadeh \& Vahdat Torbati, 2008).

Because of the importance of forgiveness and altruism for interpersonal relationships and the positive effects of these psychological structures on different areas, the relationship that exists between attachment, altruism, and level of forgiveness in the parents of the children who have usual or special needs is analyzed in this study. 


\section{METHOD}

\section{Participants}

Statistical population of the present study included mothers of the children in elementary schools of Arak City who had normal and special needs. The sample included 300 individuals (150 mothers of the children who had special needs were chosen via convenience sampling, and 150 mothers who had normal children were chosen via cluster sampling) and 131 questionnaires were filled out by mothers of the children who had special needs and 144 questionnaires were filled out by normal children's mothers.

\section{Instruments}

Attachment to spouse questionnaire

Hazen and Shaver (1987) designed this test based on categories of infants' attachments described by Ainsworth et al. and appropriately converted it to adults' interpersonal relationships. This instrument includes three descriptive statements about individual's feelings of having a relationship, intimacy, and sex with the spouse. Each statement describes one of the attachment styles i.e. secure, avoidance, and anxious. Factor analysis of this questionnaire by Colins and Rid (1990) elicited three main factors. Hazen and Shaver (1987) calculated the total retest reliability of this questionnaire about 0.81 and the reliability by Cronbach alpha about 0.78 which is a desirable reliability. Using the Main's structured interviews (1983), the concurrent validity of this instrument was calculated; it was calculated about 79 percent for secure attachment style, 84 percent for avoidance attachment, and 0.78 for insecure-anxious attachment style and its total concurrent validity was about 0.80 (Collins, \& Read, 1994). The example of the item is "for me so hard that I trust completely to others."

\section{Enright Forgiveness Inventory}

This instrument was designed by Robert Enright at Wisconsin University to measure interpersonal forgiveness. Empirical studies have shown that this test is negatively related to 
anger but positively to hope. This inventory consists of 60 items, in which 20 items are in the cognitive domain, 20 ones are in the affective domain, and 20 ones are in the behavioral domain. The correlation between different domains of this inventory is reported about 0.80 to 0.87 , which shows that all of the three domains measure one structure and that the scores of the three scales can be summed up. Correlation of affective, behavioral, and cognitive domains of the test and the criterion item at the end of inventory was respectively about $0.68,0.64$, and 0.60 . Correlation of total test and criterion item was about 0.68. The studies of Enright et al. (1991) showed that there is a negative and significant correlation (-0.43) between Beck Depression Scale and Enright Forgiveness Inventory. There is a significant and negative correlation between this test and Schpielberger Anxiety Scale. The Cronbach alpha coefficient which showed internal consistency of the test's items was 0.97. The example of the item is "while you are thinking to offensive, answer these question: for example: Now there is no issue that I think about it."

\section{Altruism Questionnaire}

Using empathy, affiliation, and forgiveness scales of Ashton et al. (1998), the Altruism Questionnaire was designed. This questionnaire evaluates two main dimensions of altruism i.e. altruism of the relatives and mutual altruism of the individuals toward each other. It consists of 16 items. The internal consistency of the Empathy/affiliation dimension of this test was 0.73 , and the internal consistency of Forgiveness/Non Retaliation dimension of the test was 0.75. The factor analysis of this inventory with varimax rotation showed that the questionnaire has consisted of two factors. Half of the questions are in Empathy/affiliation category and half of them in Forgiveness/Non-Retaliation category. According to their level of agreement, the respondents can choose one of the items through Likert scale from a little (1) to very much (5). Some of the items were inversed before summing up the scores of the subject, so a little was scored (5) and very much was scored (1). Questions 1, 2, 8, 4, 9, 12, 13, and 16were scored inversely. The reliability of this scale was examined, and the Cronbach alpha of both dimensions was more than 0.7 . The example of the item is "I would treat strangers with compassion." 


\section{RESULTS}

In this section, the data are described firstly and then inferential statistic is used for testing the hypotheses. Table (1) shows the mean and standard deviation of the study's basic variables.

Table 1

Mean and standard deviation for parents of the children with normal and special needs

\begin{tabular}{lcccc}
\hline Components & \multicolumn{2}{c}{$\begin{array}{c}\text { Parents of the children who } \\
\text { have special needs }\end{array}$} & \multicolumn{2}{c}{ Parents of normal children } \\
& Mean & SD & Mean & SD \\
\cline { 2 - 5 } & 3.18 & 1.09 & 3.09 & 1.02 \\
$\begin{array}{l}\text { Insecure attachment } \\
\text { to spouse }\end{array}$ & & & & \\
Empathy & 3.08 & 0.75 & 3.28 & 0.78 \\
$\quad$ Non-Retaliation & 3.09 & 0.53 & 3.39 & 0.46 \\
Behavioral & 3.84 & 1.01 & 4.20 & 0.73 \\
Cognitive & 4.32 & 0.80 & 4.44 & 0.99 \\
Affective & 3.82 & 0.96 & 4.22 & 0.72 \\
\hline
\end{tabular}

According to the table (1), the highest and lowest mean for the group which is consisted of normal children's parents are respectively in the cognitive domain of forgiveness (4.44) and insecure attachment to spouse (3.09). The highest and lowest mean for the group which is consisted of the parents who have children with special needs are respectively in the cognitive domain of forgiveness (4.32) and empathy (3.08). 
Table 2

Correlation of attachment and forgiveness in parents of the children with normal and special needs

\begin{tabular}{lccc}
\hline Insecure attachment to spouse & Behavioral & Cognitive & Affective \\
\hline Parents with normal children & ${ }^{\star \star}-0.460$ & ${ }^{\star}-0.175$ & $\star \star-0.262$ \\
Parents with special children & ${ }^{\star \star}-0.265$ & -0.063 & $\star \star-0.239$ \\
\hline
\end{tabular}

${ }^{*} \mathrm{P}<0.05 \quad * * \mathrm{P}<0.01$

Table (2) shows that there is a significant and negative relationship between insecure attachment to spouse and the cognitive, affective, and behavioral domains of forgiveness in the parents of normal children but there is a significant and negative relationship between insecure attachment to spouse and the behavioral and affective domains of forgiveness in the parents of the children who have special needs. To investigate the predictive of power variables for predicting the criterion variable, the step-by-step regression was utilized, and the result is firstly shown for the sample group of the mothers who have children with special needs.

Table 3

Analysis of variance for regression model of predictive variables for predicting the affective domain of forgiveness

\begin{tabular}{lccccccc}
\hline Model & $\begin{array}{c}\text { Sum of } \\
\text { squares }\end{array}$ & $\mathrm{df}$ & $\begin{array}{c}\text { Mean of } \\
\text { squares }\end{array}$ & $\mathrm{F}$ & $\begin{array}{c}\text { Level of } \\
\text { significance }\end{array}$ & $\mathrm{R}^{2}$ & adjusted \\
\hline Regression & 12.90 & 3 & 4.30 & 0.006 & $* * 0.003$ & 0.106 & 0.085 \\
Remaining & 109.15 & 127 & 0.85 & & & & \\
Total & 122.06 & 130 & & & & & \\
\hline
\end{tabular}

According to the table (3), the determination coefficient is 0.106 . It means that 10.6 percent of the variance in the affective domain of forgiveness is determined by altruism and attachment to 
the spouse. This level of changes is significant because of the amount of $F_{3.127}=0.006$ and $\mathrm{P}<0.01$. It shows that at least one of the predictive variables can predict the criterion variable. To find out which one of the predictive variables can predict the criterion variable, the beta significance test was utilized. The beta coefficient is the coefficient of changes in criterion variable based on predictive variables, shown in the Table (4).

Table 4

Standardized Alpha coefficients of predictive variables for predicting the affective domain of forgiveness

\begin{tabular}{lccccc}
\hline Predictive variables & $\begin{array}{c}\text { Regression } \\
\text { coefficients B }\end{array}$ & SE & $\begin{array}{c}\text { Regression } \\
\text { coefficients } \beta\end{array}$ & $\mathrm{t}$ & $\begin{array}{c}\text { Level of } \\
\text { significance }\end{array}$ \\
\hline Insecure attachment & -0.204 & 0.075 & 0.230 & 2.72 & $* * 0.007$ \\
Empathy & 0.179 & 0.122 & 0.139 & 1.46 & 0.147 \\
$\quad$ Non-Retaliation & 0.216 & 0.173 & 0.119 & 1.250 & 0.214 \\
\hline
\end{tabular}

Table (4) shows that the affective domain of forgiveness can be predicted by insecure attachment as the predictive variable. Insecure attachment is inversely related to forgiveness $(\mathrm{P}<0.01)$. The following table shows the prediction of cognitive domain of forgiveness in mothers who have children with special needs.

Table 5

Analysis of variance for regression model of predictive variables for predicting the cognitive domain of forgiveness

\begin{tabular}{lccccccc}
\hline Mod & Sum of & df & $\begin{array}{c}\text { Mean of } \\
\text { squares }\end{array}$ & F & $\begin{array}{c}\text { Level of } \\
\text { significance }\end{array}$ & adjusted \\
& & squares & & & & & $\mathrm{R}^{2}$ \\
\hline el & 0.457 & 3 & 0.152 & 0.230 & 0.875 & 0.005 & 0.018 \\
Regression & 84.091 & 127 & 0.662 & & & & \\
Remaining & 84.54 & 130 & & & & & \\
Total & & & & & & & \\
\hline
\end{tabular}


According to the table (5), the determination coefficient is 0.005 . It means that about 0.5 percent of the variance in the cognitive domain of forgiveness in mothers who have children with special needs is determined by altruism and attachment to the spouse. Since the determined variance is not statistically significant, none of the predictive variables has been able to predict the criterion variable. So, there is no need to follow-up and showing the beta table. The following table shows the prediction of the behavioral dimension of forgiveness in mothers who have children with special needs.

Table 6

Analysis of variance for regression model of predictive variables for predicting the behavioral domain of forgiveness

\begin{tabular}{lccccccc}
\hline \multicolumn{1}{c}{ Model } & $\begin{array}{c}\text { Sum of } \\
\text { squares }\end{array}$ & $\mathrm{df}$ & $\begin{array}{c}\text { Mean of } \\
\text { squares }\end{array}$ & $\mathrm{F}$ & $\begin{array}{c}\text { Level of } \\
\text { significance }\end{array}$ & $\mathrm{R}^{2}$ & adjusted \\
\hline Regression & 12.016 & 3 & 4.005 & 4.198 & $* * 0.007$ & 0.090 & 0.069 \\
Remaining & 121.18 & 127 & 0.954 & & & & \\
Total & 133.20 & 130 & & & & & \\
\hline
\end{tabular}

According to the table (6), the determination coefficient is 0.090 . It means that about 0.9 percent of the variance in the behavioral domain of forgiveness is determined by altruism and attachment to spouse $\left(\mathrm{F}_{3.127}=4.198\right.$ and $\left.\mathrm{P}<0.01\right)$.

Table 7

Standardized regression coefficients of predictive variables for predicting the behavioral domain of forgiveness

\begin{tabular}{lccccc}
\hline Predictive variables & $\begin{array}{c}\text { Regression } \\
\text { coefficients B }\end{array}$ & SE & $\begin{array}{c}\text { Regression } \\
\text { coefficients } \beta\end{array}$ & $\mathrm{t}$ & $\begin{array}{c}\text { Level of } \\
\text { significance }\end{array}$ \\
\hline Insecure attachment & -0.237 & 0.079 & 0.257 & 3.008 & $* * 0.003$ \\
Empathy & 0.196 & 0.129 & 0.146 & 1.52 & 0.130 \\
$\quad$ Non-Retaliation & 0.043 & 0.182 & 0.023 & 0.23 & 0.81 \\
\hline
\end{tabular}


Table (7) shows that the behavioral domain of forgiveness can be predicted by the predictive variable namely insecure attachment to the spouse in parents of the children who have special needs. Insecure attachment is inversely related to forgiveness $(\mathrm{P}<0.01)$. To investigate the power of predictive variables for predicting the criterion variable in the sample group of the mothers who have normal children, the step-by-step regression was utilized, and the result is shown in the following.

Table 8

Analysis of variance for regression model of predictive variables for predicting the cognitive domain of forgiveness

\begin{tabular}{lccccccc}
\hline Model & $\begin{array}{c}\text { Sum of } \\
\text { squares }\end{array}$ & df & $\begin{array}{c}\text { Mean of } \\
\text { squares }\end{array}$ & $\mathrm{F}$ & $\begin{array}{c}\text { Level of } \\
\text { significance }\end{array}$ & $\mathrm{R}^{2}$ & adjusted \\
\hline Regression & 14.97 & 3 & 4.99 & 5.46 & $* * 0.001$ & 0.105 & 0.086 \\
Remaining & 127.87 & 140 & 0.913 & & & & \\
Total & 142.85 & 143 & & & & & \\
\hline
\end{tabular}

According to the table (8), the determination coefficient is 0.105 . It means that about 10.5 percent of the variance in the cognitive domain of forgiveness is determined by altruism and attachment to the spouse in parents of normal children $\left(\mathrm{F}_{127.3}=5.46\right.$ and $\left.\mathrm{P}<0.01\right)$.

Table 9

Standardized regression coefficients of predictive variables for predicting the cognitive domain of forgiveness

\begin{tabular}{lccccc}
\hline Predictive variables & $\begin{array}{c}\text { Regression } \\
\text { coefficients B }\end{array}$ & SE & $\begin{array}{c}\text { Regression } \\
\text { coefficients } \beta\end{array}$ & $\mathrm{t}$ & $\begin{array}{c}\text { Level of } \\
\text { significance }\end{array}$ \\
\hline Insecure attachment & -0.387 & 0.114 & -0.303 & 3.40 & $* * 0.001$ \\
Empathy & 0.135 & 0.175 & 0.063 & 0.770 & 0.442 \\
$\quad$ Non-Retaliation & 0.054 & 0.085 & 0.055 & 0.629 & 0.530 \\
\hline
\end{tabular}


Table (9) shows that the cognitive domain of forgiveness can be predicted by insecure attachment to the spouse as a predictive variable. Insecure attachment is inversely related to forgiveness $(\mathrm{P}<0.01)$. The following table shows the prediction of affective domain of forgiveness in mothers who have normal children.

Table 10

Analysis of variance for regression model of predictive variables for predicting the affective domain of forgiveness

\begin{tabular}{lccccccc}
\hline Model & $\begin{array}{l}\text { Sum of } \\
\text { squares }\end{array}$ & df & $\begin{array}{c}\text { Mean of } \\
\text { squares }\end{array}$ & $\mathrm{F}$ & $\begin{array}{c}\text { Level of } \\
\text { significance }\end{array}$ & $\mathrm{R}^{2}$ & adjusted \\
\hline Regression & 12.26 & 3 & 4.088 & 9.12 & $* * 0.001$ & 0.164 & 0.146 \\
Remaining & 62.69 & 140 & 0.448 & & & & \\
Total & 74.95 & 143 & & & & & \\
\hline
\end{tabular}

According to the table (10), the determination coefficient is 0.164 . It means that about 16.4percent of the variance in the affective domain of forgiveness is determined by altruism and attachment to spouse $\left(\mathrm{F}_{3,140}=9.12\right.$ and $\left.\mathrm{P}<0.01\right)$.

Table 11

Standardized regression coefficients of predictive variables for predicting the affective domain of forgiveness

\begin{tabular}{lccccc}
\hline Predictive variables & $\begin{array}{c}\text { Regression } \\
\text { coefficients B }\end{array}$ & SE & $\begin{array}{c}\text { Regression } \\
\text { coefficients } \beta\end{array}$ & $\mathrm{t}$ & $\begin{array}{c}\text { Level of } \\
\text { significance }\end{array}$ \\
\hline Insecure attachment & 0.297 & 0.080 & 0.321 & 3.729 & $* * 0.001$ \\
Empathy & 0.082 & 0.123 & 0.052 & 0.665 & 0.50 \\
$\quad$ Non-Retaliation & 0.092 & 0.060 & 0.131 & 1.545 & 0.125 \\
\hline
\end{tabular}


Considering the beta coefficient, the affective domain of forgiveness is predicted by insecure attachment to the spouse as the predictive variable in parents of normal children. The following table shows the prediction of the behavioral domain of forgiveness in mothers of normal children.

Table 12

Analysis of variance for regression model of predictive variables for predicting the behavioral domain of forgiveness

\begin{tabular}{lccccccc}
\hline Model & $\begin{array}{c}\text { Sum of } \\
\text { squares }\end{array}$ & $\mathrm{df}$ & $\begin{array}{c}\text { Mean of } \\
\text { squares }\end{array}$ & $\mathrm{F}$ & $\begin{array}{c}\text { Level of } \\
\text { significance }\end{array}$ & $\mathrm{R}^{2}$ & adjusted \\
\hline Regression & 0.996 & 3 & 0.333 & 0.602 & 0.615 & 0.013 & 0.008 \\
Remaining & 77.191 & 140 & 0.551 & & & & \\
Total & 78.186 & 143 & & & & & \\
\hline
\end{tabular}

According to the table (12), the determination coefficient is 0.013 . It means that about 1 percent of the variance in the behavioral domain of forgiveness is determined by altruism and attachment to the spouse. Since the determined variance is not statistically significant, none of the predictive variables has been able to predict the criterion variable. So, there is no need to follow-up and showing the beta table.

\section{DISCUSSION}

The purpose of present study was to investigate the relationship between attachment to spouse, altruism, and forgiveness in parents of the children who have normal and special needs children. Findings of the present study showed that insecure attachment to the spouse was significantly and negatively related to cognitive, affective, and behavioral domains of forgiveness in normal children's mother's group. On the other side, insecure attachment to the spouse was significantly and negatively related to behavioral and affective domains of forgiveness in parents of the 
children who have special needs. In other words, insecure attachment to spouse leads to the reduction of forgiveness among the parents in both groups (Table 2). Attachment plays an important role in the personal ability to establish the relationship among adults and in keeping a respectful mutual relationship between the two individuals in all stages of life (Dwyer, 2000; Feeney, 1996; Mikulincer \& Shaver, 2005; Feeney \& Hohaus, 2001; Kunce \& Shaver, 1994). According to a study by Lawler-Row and Piferi. (2006), the individuals who have secure attachment style are more willing to forgive special agonies, show higher levels of the forgiveness trait, and have more positive emotions. Their findings show that attachment style may be an independent antecedent for forgiveness. Likewise, according to the findings of Brunette and et al. (2007), the individuals who have secure attachment style show more instinct readiness to forgive than the individuals who have an insecure attachment.

With no doubt, when the family has a child who has special needs, the members of that family, especially the mother, would have to endure a lot of anxiety. Results of studies show that the mothers who have children with special needs are in a more critical condition than the mothers who have normal children so that they might show prejudgment, anger, grudge, and lack of forgiveness (Abidin, 1992; Heiman \& Berger, 2008). Mikulincer and et al. (2001, 2002, 2005). Secure attachment increases pitiable and altruistic responses, but insecure attachment acts inversely. Secure attachment lets the individuals take the personal viewpoint of the people who have a tension-the fundamental mechanism of altruism- into consideration. In fact, the individuals who have secure attachment style enhance helping through improving the person's mood, experiencing the empathic joy (Smith, Keating \& Stotland,1989; Cialdini, Brown, Lewis, Luce, \& Neuberg, 1997) and so on and move their own supportive resources toward others without getting worried (Mikulincer \& Shaver, 2005). One the other hand, the individuals who have avoidance and anxious style fail to have an appropriate altruistic behavior and since they often pay attention to their problems fail to understand the problems of other people and to show altruistic behavior (Collins \& Read, 1994). In other words, according to Bowlby, since a person needs immediate support in threatening situations, he/she may pay attention to the individuals who support him/her in those situations rather than trying to support the other people. He/she tries to help other people only when he/she feels safe (Main, 1983). 
Therefore, the parents who have children with special needs experience more critical situations and stress. Stress and feeling insecure caused by insecure attachment to spouse become exacerbated when coexisting with the crisis of having a disable child. As a result, without paying attention to empathy and altruism, their judgment and supportive behaviors are affected, and their level of forgiveness decreases. Nevertheless, these parents have cognitive distortion because of experiencing high levels of stress. So, the supportive system excessively affects behavioral and affective domains of forgiveness (Table 4 and 7). Interpretations of these findings show that there are important similarities between attachment theory and forgiveness. Both of them include some constructs such as trust, relationship, empathy, emotional autonomy, and a complex set of psychological changes focused on oneself and others. Forgiveness often requires empathy and coping with feelings of self-doubt, guilt, and anger (Enright \& Human Development Study Group, 1991). In threatening situations, the forgiveness process is facilitated by secure attachment (Gillath, Shaver \& Mikulincer, 2005). The concerns and worries that the individuals with insecure attachment style have to prevent having empathy with the wrongdoer or controlling the negative emotions. On the other side, secure attachment reduces the need to support and punish oneself and lets the individual take other people's viewpoint into consideration and control his/her anger (Mikulincer \& Shaver, 2001, 2003). Because of having no feeling of empathy and inability to control their negative feelings, the individuals with insecure attachment style cannot forgive other people. Attachment theory and other studies have highlighted the similarities between attachment styles and forgiveness predictors. For instance, while the individuals who have secure attachment style show a lot of positive characteristics that forgivers have such as self-adjustment, empathy, and adaptation, the individuals who do not forgive and have insecure internal patterns react to threatening communicational events negatively, emotionally, and behaviorally, have negative ruminations, and are prone to depression (Simpson, Rholes, Nelligan, 1992).

Findings of the present study showed that attachment to spouse, altruism, and forgiveness could significantly determine the changeability of the relationships two individuals have. So, two theoretical and practical outcomes of the study are mentioned. In the practical level, providing 
the educational and interventional programs to enhance forgiveness and altruism can teach efficient and suitable skills and strategies to the spouses to enhance society's mental and general health. In the theoretical level, findings of the present study can add to the richness of present theories about forgiveness, altruism, and attachment to spouse and make new hypotheses and questions rise.

\section{Limitations}

Several aspects of this study can limit the application of the findings: first, the correlation nature of the study serves only as evidence of the relationship between independent variables and forgiveness and does not show causality. Second, despite using a well-designed methodology and sampling method, the generalization of the results is limited only to the parents in the city of Arak.

\section{Acknowledgement}

The authors were involved in the design of the study and contributed to and have approved the final manuscript. The authors would like to acknowledge all the participants of the study.

\section{REFERENCES}

Abidin, R. R. (1992). The determinants of parenting behavior. Journal of Clinical Child Psychology, 21(4), 407-412.

Batson, C. D. (1991). The altruism question: Toward a social psychological answer. Hillsdale, NJ: Erlbaum.

Berry, J. W., Worthington, E. L. (2001). Forgivingness, relationship quality, stress while imagining relationship events, and physical and mental health. Journal Counseling Psychology, 48(4), 447-455.

Bono, G., McCullough, M. E, \& Root, L. M. (2008). Forgiveness, feeling connected to others, and wellbeing: two longitudinal studies. Personal Social Psychology Bulletin, 34(3), 182195.

Bowlby, J. (1969). Attachment and loss: Vol. 1. Attachment. New York: Basic Books.

Bowlby, J. (1980). Attachment and loss: Vol. 3. Sadness and depression. New York: Basic Books. 
Journal of Educational, Health and Community Psychology

Brunette, J. L., Taylor, K. W., Worthington, E. L., \& Forsyth. D. R., (2007). Attachment and trait forgiveness: The mediating role of angry rumination. Personality and Individual Differences, 42, 1585-1596.

Burnette, J. L., Davis, D. E., Green, J. D., Worthington, E. L., Bradfield, E. (2009). Insecure attachment and depressive symptoms: The mediating role of rumination, empathy, and forgiveness. Personality and Individual Differences, 46, 276-280.

Chun Thai, S. P. (2012). The Role of Attachment Avoidance in Social Comparisons between Romantic Partners. A thesis submitted in conformity with the requirements for the degree of Master of Arts Department of Psychology University of Toronto.

Cialdini, R. B., Brown, S. L., Lewis, B. P., Luce, C., \& Neuberg, S. L. (1997). Reinterpreting the empathy-altruism relationship: When one into one equals oneness. Journal of Personality and Social Psychology, 73, 481-494.

Collins, N. L, Read, S. J. (1990). Adult attachment, working models, and relationship quality in dating couples. Journal of Personality and Social Psychology, 58(4), 644-63.

Collins, N. L., \& Read, S. J. (1994). Cognitive representations of attachment: The structure and function of working models. In K. Bartholomew \& D. Perlman (Eds.), Attachment processes in adulthood (pp. 53-92). London: Jessica Kingsley.

Crowell, J. A., \& Feldman, S. S. (1991). Mothers' working models of attachment relationships and mother and child behavior during separation and reunion. Developmental Psychology, 27, 597-605.

Dwyer, D. (2000). Interpersonal relationships. London: Rutledge Pub.

Enright, R. D., \& Human Development Study Group. (1991). The moral development of forgiveness. In W. Kurtine \& J. Gewirtz (Eds.), Handbook of Moral Behavior and Development, 1, 123-152. Hillsdale, NJ: Erlbaum.

Enright, R. D., Santos, M. J., \& Al-Mabuk, R. (1989). The adolescent as a forgiver. Journal of Adolescence, 12(1), 95-110.

Feeney, J. A. (1996). Attachment, caregiving, and marital satisfaction. Personal Relationships, 3, $401-416$.

Feeney, J. A., \& Hohaus, L. (2001). Attachment and spousal caregiving. Personal Relationships, $8,21-39$.

Fincham, F. D. (2000). The kiss of the porcupines: From attributing responsibility to forgiving. Personal Relationships, 7(1), 1-23.

Ghobari Bonab, B., Kivanzadeh, M \& Vahdat Torbati, S. (2008). Study of relation among forgiveness and mental health in University of Medical Sciences. Journal of Psychology and Educational Sciences, 79, 167-180.

Gillath, O., Shaver, P. R., \& Mikulincer, M. (2005). An attachment theoretical approach to compassion and altruism. In P. Gilbert (Ed.), Compassion: Its nature and use in psychotherapy (pp. 121-147). London: Brunner-Routledge 
Journal of Educational, Health and Community Psychology

Hallahan, D. P., Kauffman, J. M., \& Pullen, P. C. (2014). Exceptional learners: Introduction to special education (15th ed.). Boston. Allyn \& Bacon.

Hazen, C., Shaver, P. (1987). Attachment as an organizational framework for research on a close relationship. Psychological Inquiry, 5, 7-22.

Heiman, T., \& Berger, O. (2008). Parents of children with Asperger syndrome or with learning disabilities: Family environment and social support. Research in Developmental Disabilities, 29(4), 289-300.

Huang, S.T., Enright, R. D. (2000). Forgiveness and anger related emotions in Taiwan: Implications for therapy. Psychotherapy: Theory, Research, Practice, Training, 37(1), 71-79.

Kardatzke , K. N.(2009). Perceived Stress, Adult Attachment, Dyadic Coping and Marital Satisfaction of Counseling Graduate Students. Unpublished doctoral dissertation. Greensboro University.

Kauffman, J. M., \& Hallahan, D. P. (2011). Handbook of Special Education. ERIC.

Kestenbaum, R., Farber, E. A., \& Sroufe, L. A. (1989). Individual differences in empathy among preschoolers: Relation to attachment history. In N. Eisenberg (Ed.), Empathy and related emotional competence. Vol. 44, 838 New Directions for Child Development (pp. 51-64). San Francisco: Jossey-Bass.

Kunce, L. J., \& Shaver, P. R. (1994). An attachment-theoretical approach to caregiving in romantic relationships. In K. Bartholomew \& D. Perlman (Eds.), Advances in personal relationships (Vol. 5, pp. 205-237). London: Jessica Kingsley.

Lawler, K. A., Younger , J. W., Piferi, R. L., Billington, E., Jobe, R., Edmondson, K., \& et al. (2003). Change of heart: Cardiovascular correlates of forgiveness in response to interpersonal conflict. Journal of Behavior Medicine, 26(5), 373-393.

Lawler-Row, K. A., Karremans, J. C., Scott, C., Edlis- Matityahou, M., \& Edwards, L. (2008). Forgiveness, physiological reactivity, and health: the role of anger. Internal Journal of Psychophysiology, 68(1), 51-58.

Lawler-Row, K. A., Piferi, R. L. (2006). The forgiving personality: describing a life well lived? Personal Individual Differences, 41(6), 1009-1020.

Main, M. (1983). Exploration, play, and cognitive functioning related to infant-mother attachment. Infant Behavior \&Development, 6(2), 167-74.

McCullough, M. E, Witvliet, C. V. (2002). The psychology of forgiveness. In C. R. Snyder \& S. J. Lopez (Eds.). Handbook of positive psychology (pp. 446-458). New York, NY: Oxford University Press.

Mikulincer, M \& Shaver, P. R. (2001). Attachment theory and intergroup bias: Evidence that priming the secure base schema attenuates negative reactions to out-group. Journal of Personality and Social Psychology, 81, 97-115.

Mikulincer, M \& Shaver, P. R. (2003). The attachment behavioral system in adulthood: Activation, Psychodynamics, and interpersonal processes. In M. P. Zanna (Ed.), Advances in experimental social psychology (35, pp. 53-152). San Diego, CA: Academic Press. 
Journal of Educational, Health and Community Psychology

Mikulincer, M \& Shaver, P. R. (2005). Attachment, Care giving and Altruism: Boosting Attachment Security Increases Compassion and Helping. Journal of Personality and Social Psychology, 85(5), 817-839.

Miller, T. Q., Smith, T. W., Turner, C. W., Guijarro, M. L., Hallet, A. J. (1996). A meta-analytic review of research on hostility and physical health. Psychological Bulletin, 119(2), 322-348.

Pietromonaco, P. R., \& Barrett, L. F. (2000). The internal working models concept: What do we really know about the self in relation to others? Review of General Psychology, 4, 155-175.

Simpson, J. A., Rholes, W. S., Nelligan, J. S. (1992). Support seeking and support giving within couples in anxiety provoking situation: The role of attachment styles. Journal of Personality and Social Psychology, (62)3, 434-46.

Smith, K. D., Keating, J. P., \& Stotland, E. (1989). Altruism revisited: The effect of denying feedback on a victim's status to an empathic witness. Journal of Personality and Social Psychology, 57, 641-650.

Soerensen, S., Webster, J. D., \& Roggman, L. A. (2002). Adult attachment and preparing to provide care for older relatives. Attachment and Human Development, 4, 84-106.

Toussaint, L., \& Webb, J. R. (2005). Theoretical and empirical connections between forgiveness, mental health, and well-being. Handbook of forgiveness, 349-362.

Vandervort, D. J. (2006). Hostility and health: Mediating effects of belief systems and coping styles. Current Psychology: Developmental, Learning, Personality Social, 25(1), 50-66.

Wearden, A., Peters, I.; Berry, K.; Barrowclough, C. h \& Liversidge, T. (2008). Adult attachment, parenting experiences, and core beliefs about self and others. Personality and Individual Differences 44 (2008) 1246-1257.

Webb, J. R. (2003). Forgiveness, health, and well-being among people with spinal-cord injury. APA Annual Convention. American Psychology Association.

Westmaas, J. L., \& Silver, R. C. (2001). The role of attachment in responses to victims of life crises. Journal of Personality and Social Psychology, 80, 425-438.

Wiederman, M. W., Allgeier, E. R. (1996). Expectations and attributions regarding extramarital sex among young married individuals. Journal of Psychology and Human Sexuality, 8, 2135 .

Worthington Jr, E. L., Witvliet, C. V. O., Pietrini, P., \& Miller, A. J. (2007). Forgiveness, health, and well-being: A review of evidence for emotional versus decisional forgiveness, dispositional forgivingness, and reduced unforgiveness. Journal of Behavioral Medicine, 30(4), 291-302.

Worthington, E. L. \& Scherer, M. (2004). Forgiveness as an emotion-focused coping strategy that can reduce health risks and promote health resilience. Theory, review, and hypotheses. Psychological Health, 19(3), 385-405. 